\title{
The Characteristics and Enlightening of NCATE
}

\author{
Caiping Wang \\ School of Management, Tianjin Polytechnic University \\ 399 Bin Shui West Road Yan Chang Xian, Tianjin 300387, China \\ Tel: 86-22-8193-5114 E-mail: wangluck2008@163.com \\ Xialing Chen \\ School of Management, Tianjin Polytechnic University \\ 399 Bin Shui West Road Yan Chang Xian, Tianjin 300387, China \\ E-mail: chenxialing@12.6com
}

\begin{abstract}
Accreditation system of teacher education institutions is an important ensuring mechanism for teacher's profession. American accreditation system of teacher education institutions refers to an assessment system that the National Council for Accreditation of Teacher Education (NCATE) with the institution's application, making regular evaluation of the teacher education institutions according to the accreditation standards formulated by the National Council for Accreditation of Teacher Education, which abbreviates NCATE accreditation. NCATE is the first appraisal institution of national teacher education, which constantly improves the training quality of American teachers by being comprehensively appraised. It has been exerting great influence on the development of teacher education in America. And the effects are as following: convenient for students' mobility among schools and the teachers' transference to other states; encouraging competition among teacher education institution and academic mobility; leading to the regular internal assessment in teacher education institutions and promoting the professional level of pre-service education; and helping establish a quality assurance system for teacher education. The paper introduces the characteristics of NCATE and draws out enlightening points and reference for our institution accreditation of teacher education
\end{abstract}

Keywords: NCATE, America, Teacher Education Institutions

Having good accreditation system of teacher education institutions can insure education quality pre-post and provide a good base for special development for teachers. Building a system of teacher education institutions with Chinese characteristics is an important and hot issue in the field of teacher education. America with relatively perfect teacher education mechanism has formed a more mature and perfect system of institution accreditation o f teacher education, we should learn and refer the good measures that play an important influence on normalizing the institution and improving the specialization of teacher education.

\section{General description of NCATE}

NCATE is first one specialized accreditation institution of national teacher education supported by the United States Department of Education and the Council of Higher Education Accreditation, and it is the most senior and authentic academic accreditation institution. NCATE was built in 1951 under the help of American Association of Colleges for Teacher Education, National Association of Sate Directors of Teacher Education and Certification, Council of Chief Sate School Officers, National School Boards Association, National School Boards Association. NCATE has replaced American Association of Colleges for Teacher Education (AACET) and has engaged in accreditation work of national teacher education institutions since 1954. And appraising the school level of national institutions of teacher education is its mayor function. For 50 years, NCATE has played a vital role in teacher education development in American history, the number of teacher education institutions applying for accreditation has been adding, specially developing fast in recently several years. Only 32 teacher education institutions were candidate or pre-candidates of NCATE, 478 teacher education institutions got accredited in 1995 . About 670 teacher education institutions have joined accreditation system of NCATE by 2003, and 526 teacher education institutions got accredited. In addition, 110 teacher education institutions have become formal candidate or pre-candidate of NCATE.

NCATE is a non-government and non-profit specialized organization. It is supported, composed and managed by 35 
national specialized organizations. These educational specialized organizations come from following four kinds of organizations: teacher education, teachers, sate and local policymakers, professional associations. NCATE adapts accreditation standards every five years and forms a relatively perfect accreditation system of teacher education in terms of the development of social and economy, which plays important influence on the development of American teacher education: making students move freely between schools and teachers have class in anther state; encouraging teacher education institutions to compete and enlarging academic freedom; promoting regularly teacher education institutions interior assessment and unceasingly improving specialized level of teachers. The main function of NCATE is to make comprehensively appraisal of education content, specialty arrangement, curricular regulation, teacher qualification, management condition, student status, school condition, and so on. The goal of NCATE is to improve the quality o $\mathrm{f}$ teacher education, guide teacher education institutions to transformation. And NCATE is sure every student to be patient to study under the instruction of teachers, so NCATE pay attention to three core assignments: the first one is performance accountability of pre-post; the second one is improvement of pre-post; the third one is to provide leadership of teacher education.

\section{The contents and characteristics of accreditation standards of NCATE}

Because accreditation standards of NCATE have the function of guide, restriction, regulation, accreditation standards of NCATE were adjusted and supplemented in 2000, so we find the great change of education practice of teachers. The revision of accreditation standards is opened under the background of building education system in the 21st century, reflecting the feature of contemporaneity and foresightedness for specialized demand of teacher education. Every unit criteria of NCAIE is made up of three parts: Proper language expression; Three-grade description contained in basic content of the criteria, which is acceptable, unacceptable, target; Explanation of criteria. Its concrete contents and characteristic is as following:

\subsection{Knowledge, skill and disposition of professional teacher candidates.}

NCATE require teachers must to be equipped with deep and large specialty knowledge to help all students of twelve-year study, here " all students" means needing all kinds of special education, or the students with the different race, cultural, language, religion, gender, region as well as socio-economic background. The guideline of professional teachers is that the study of students is the goal of teaching, the accreditation of NCATE stresses importance of the goal, which requires teacher candidates to teach efficiently by using special knowledge and skill, at the same time, the other staff of school should support the study of students.

Accreditation standards of NCATE says that teacher candidates should be qualified with knowledge, skill and disposition, and teachers who are going to work in school must be equipped with necessary subject content, pedagogy, specialty knowledge skill and characteristic what students learn. Teacher candidates can analyze and evaluate the study of students, which shows teacher candidates must accord with the criteria of and teacher education institutions, which is based on teaching study now, every element is important to help students to study, which should be showed in the concept frame of teacher education institutions, and become one great part of accreditation system. The data of accreditation system should be used for reflecting the study situation of teacher candidates in specialty knowledge, teaching method and specialty moral.

\subsection{Assessment system and unit evaluation.}

Teacher education institutions should also a assessment system so as to collect and analyze the qualification of applicants, the performance of teacher candidates, graduates and the data of it, as a result that we can assess and improve the teacher education institutions and cultivating plan. NCATE has made appraisal performance standards for teachers and educational institutions, also compiled the subjects of the standard as a supplement. Accreditation standards of NCATE for student learning evaluation focus teacher candidates who achieve the monitoring the above objective, appraisal is carried according to real behavior of the students in critical thinking, solving problems, and performance skills.

Accreditation standards of NCATE says that teacher education institutions should have one kind of appraisal system or related appraisal plan, involving 5 aspects: To be able to monitor performance and result of teacher candidates, operation of organization ; Implementing appraisal in many ways; Performance appraisal should pass through the process of teachers candidate from to enrollment to graduation; Fair, accurate and continuous appraisement is occurred in every link of the whole training process; Performance appraisal from enrollment to graduation can indicate whether teacher candidates can become qualified teachers. NCATE also stipulates that the whole appraisal process must be based on the data, regularly collect, analysis and the summarizing data, and further analyses the reform of teacher education institutions by systematically using the data so that we can encourage teacher candidates and staff to reflect and improve.

\subsection{Field experience and clinical practice}

In recent years, an important part of teacher education, Professional Development Schools (PDS) of American teachers 
have been gradually established as a system, and accreditation standards of NCATE also adopt the concept of PDS. NCATE specially formulated and has issued the PDS standard in 2001, which implies America pay great attention to teaching practice. Regarding field experience and clinical practice as a separate standard in accreditation standards of NCATE, which suggests that practice activity is an essential part of teacher education. Teacher education and schools should together involve field experience and clinical practice so as to ensure develop and use the necessary knowledge that students learn.

Accreditation standards of NCATE says that teacher institutions should get touch with school, together design , carry and appraise concept frame and item of appraisal institution, participate in the activity of specialty development and the education item for teacher candidates and students, communicate specialty knowledge and resource so as to support the study of teacher candidates. At the same time, teacher institutions and schools should involve in field experience and clinical practice. In teaching activity, teacher candidates should observe the activity of themselves and other candidates. Teacher candidates take part in school activity with teachers, family, students, university or college managers, so that the teaching quality can be improved. Teacher candidates should develop and use specialty knowledge in order to back up the study of students who come from different background of folk-custom, race, language, gender and social economy.

\subsection{Diversity}

Teacher education institutions design, implement and evaluate the subject and experience of teacher candidates, so that they can acquire and use the knowledge, skill and characteristic that is helpful to study for students. These experiences include the cooperation with college teachers, middle school teachers, primary school teachers and student group with diversity. The content of appraisal includes the diversity what teacher candidates perform and use. The goal is to require teachers to be equipped with diverse culture and global view. So it is responsible for teacher candidates to provide chance to know the diversity and equity in teaching process. Subject, practice and teaching activity can help candidates to realize the importance of culture for education, and providing meaningful study experience and ability for student development.

Accreditation standards of NCATE says that teacher education institutions should prove teaching level of teacher candidates and make appraisal for them; subject and teaching practice should focus the importance of diversity; teacher candidates should know the class manner, school manner and different study way o f students, so that they can adjust teaching way and make students study well; Teachers should be equipped with diversity knowledge and skill in teaching and teacher education institutions can try to maintain and strengthen the diversity of teacher faculty; teacher candidates who come from different race, nation and gender should work together well and enter into student groups with diversity background; finally teacher candidates can accept feedback advice from colleague so that make themselves reflect better.

\subsection{Faculty qualification, performance and development}

Teacher education should try to make good progress in academe, teaching service, teaching practice and related training item, appraising teachers, reinforcing cooperation with colleague, primary and middle school. Performance and development of teachers are appraised by teacher education institutions. Teacher education institutions play an important role on cultivating specialty teachers with high quality, which can help teach candidates to develop teaching tactic with diversity and help students go study. The academe vigor of teachers can help teacher candidates to set up the stage of professional development, because they know the standard of vocation, state and institution, so that teacher candidates can meet the standards.

Accreditation standards of NCATE says that the faculty of professional education should have the doctor degree or be experts; The elementary and middle schools teachers should have the teacher qualifications; Clinical teachers from higher education to have contemporary professional experiences, the teachers should set the best practice example for us; The teachers should know well the discipline content; Teaching should reflect the concept frame of teacher education institutions; They should appraise the study of teacher candidates, as well as result performance; Using many kinds of teaching strategy; The teachers should encourage teacher candidates to develop the ability of thought and solving questions; At the same time, teachers should serve institute, university, elementary and middle schools, even community; Teacher education institutions should regularly and comprehensively appraise professional teachers of teaching, academic, achievement, service, cooperated communication and leadership ability.

\subsection{Institution management and resource.}

The teacher educational institutions in order to enable the teacher candidates to meet the standards of specialty, state and university, should provide the best management, funds budget, teachers, teaching facility, as well as resources which including many kinds of information technology. Therefore, teacher education institutions play a key leading role in management, supervising curriculum arrangement of teacher education, instruction and resource. The key element of system is the development and implement of evaluation, including data collected regarding the performance of teacher 
candidates go ensure teacher candidate to meet the standard of the state. Institution and staff should create active work circumstance to improve intelligence activity, even teaching activity and academe activity. Policy and assignment can make the staff engage in teaching, academy and service actively and efficiently.

Accreditation standards of NCATE say that the teacher educational institutions should have sufficient teaching, scientific research, appraisal and consultative time and manage the training plan effectively. The specialized team should participate in design, implement and appraising teacher education institutions and their training plans. The key part of the system is to evaluate the development and implement of system, which including colleting the data of performance of teacher candidates to guarantee them to meet the criteria. The organization should have sufficient campus facility and help teacher candidates to meet the demand. At the same time, these facilities can help teachers and students to utilize the information technique in the teaching process. The organization also should provide the sufficient people and rich resource to ensure candidates to meet the standards of vocation, state and institution, information technology resources among them for teachers and institution is necessary .The library, curriculum resource and electronic information resource can be used by teachers and students.

\section{Enlightening Points and Reference for Our Institution Accreditation of Teacher Education.}

Nowadays, the specialization of teacher education is the trend of international teacher education, but perfecting the accreditation system of teacher education institution is the important condition of the specialization of teacher education. The system of teacher education is consummated in America, and having a mature and perfect system of teacher education, many measures play an important role on regulating teacher education institution and improving the specialization of teacher education, which is worth learning and absorbing.

\subsection{Improving the specialization level of teachers.}

Accreditation standards of NCATE is set down on the base of special criteria of teaching and teacher qualification, and put forward strict demand for teaching development of normal students, reforming the interior evaluation of schools and teaching condition, and so on. The normal students are equipped with basic qualification, such as teaching skill, subject knowledge and education theory. Nowadays, teacher education develops fast in quality and quantity with the development of higher education. And it can meet for higher requirement of teachers from basic education instead of the demand for basic education teachers in number, the demand has changed from quantity to quality. The era of specialization of teacher education is coming, so it is necessary to establish specialized criteria of teacher education, make assessment of normal university and comprehensive universities in teaching condition, subject setup, teachers, the quality of graduates, and so on. Encouraging teacher education institutions improves the cultivating plan, enhances the specialized level and ensures the quality of teachers.

\subsection{Stressing the status and role of practice in teacher education.}

One important reason of teacher education reform is that theory and practice of teacher education is separated seriously, because the separation does not guarantee the actual effect and the quality of teacher education, even does not meet the demand of the national education reform. In recent years, much research about teacher education in America has proved the importance of practice in teacher education. Not only experienced teachers, but also new teachers have viewed practice activity as the most important and effective factor in teacher education. However, looking from our country's teacher education, the teaching practice has not been obtained the powerfully protected in pre-post training stage and its function has not been displayed. So it is necessary to carry field experience or clinical practice.

\subsection{Encouraging fair competition between teacher education institutions by exterior appraisal.}

The transformation of teacher education system means the structure of division labor within teacher education of all levels is being established.The higher normal colleges and non-normal universities invest resource in teacher education connecting with accreditation and supervision of teacher education institutions. Under this situation, our country also must establish and perfect accreditation system of teacher education institutions, carry out regular inspection in all normal colleges and non-normal universities that shoulder teacher education duty. And ranking teaching level of teacher education institutions is similar to we rank classification of the similar medical institutions. With a result, ultimate accreditation result can regulate resource invested in teacher education by government so as to encourage teacher education institutions of all levels to compete fairly.

\subsection{Reinforcing interior appraisal system of teacher education institutions}

Teacher education institutions should have perfect evaluation system to provide obvious evidence of teaching ability of graduate, therefore teacher education institutions must have consummate appraisal system, including enrollment, process and graduation appraisal, the perfect appraisal system will pass through the whole education process, including enrollment, process and graduation evaluation, and the perfect appraisal system will pass through the whole education process, only this skill and disposition of teachers be can disclosed in a measurable way. Accreditation standards of NCATE pay attention to the goal supervision of teacher candidates, and evaluation is carried according to critical 
thought, the ability to solve the problems and performance so as to get accurate evaluation. In our country, establishing interior appraisal system of teacher education institution can teacher be clear about the education goal and accurately grasp curriculum setup, teaching quality, teaching practice and management level of teaching and adapt to the different demand from the diversity society.

\section{References}

American Association of Colleges for Teacher Education. (2004). Comparison of NCATE and TEAC Process for Accreditation of Teacher Education. http://www.aacte.org./April.10.

Jie Zhang. (2006). References and Improving---- Enlightening from American NCATE Accreditation Standards, Higher Education Admistration China Realities And Prospects, Guang Xi Normal University Press. October.

Junajuan Wang. (2002). On America's Accreditation System of Teacher Education Institutions, Master degree thesis. (June)

Qiang Yu. Enlightening from Qualification Accreditation System of Foreign Teachers, Modern Education Science.

Xuefeng Liu. (2007). NCATE and America Teacher Education Institutions and Enlightening, Journal of Education Exploration. May.

Yugang Wu. (2006). Historical Review of Qualification Accreditation System of American Teachers, Journal of Inner Mongolia Normal University. March. 